\title{
Eliminating the problem of emergency housing using the example of the city of Omsk
}

\author{
Tatiana Avilova ${ }^{1,}{ }^{*}$, Ludmila Oznobihina ${ }^{1}$, and Anna Ermakova ${ }^{1}$ \\ ${ }^{1}$ Tyumen Industrial University, Lunacharskogo Street, Building 2, Room 104, 625000, Tyumen, \\ Russia
}

\begin{abstract}
The article considers and analyzes the problems of emergency housing in the city of Omsk. The existing approaches to the elimination of the problem of emergency housing and proposals for improving housing policy and mechanisms for its implementation are considered. As a result of the study, we came to the conclusion that the problems that exist today in the field of emergency housing need to be addressed comprehensively, using all kinds of available mechanisms and tools. It turns out that through the adoption and implementation of certain measures, we will not be able to resolve and resolve problems in various aspects of this issue.
\end{abstract}

\section{Introduction}

An integrated approach to housing management considers the housing stock as a set of interrelated elements. It allows you to look deeper and better at their essence, organization, methods of influence, and management system.

The process approach, as one of the management concepts, is a perfect management process consisting of interrelated actions. Management of housing emergency Fund reproduction can be represented as a set of repetitive processes. The use of a systematic approach in the management of housing stock reproduction allows for a deeper and better understanding of the organization process and finding the best ways and methods of influencing the management system.

From the standpoint of system approach management housing emergency Fund at the level of large city - is the integrity of the goals, objectives, management functions of emergency shelter, technologies, tools, resources, investments in reconstruction and modernization of old housing, innovation, and investment in the implementation of national programmes and projects, criteria of reducing the proportion of unfit housing.

Management of emergency housing stock from the perspective of a process approach at the level of a large city is a process consisting of interrelated management functions (forecasting, planning, organization, motivation, accounting, analysis, evaluation, and control of emergency housing costs) aimed at reproducing the housing stock[1].

Today, the problem of emergency housing is extremely acute and requires new nonstandard solutions, financial support, improving the legal framework and taking urgent measures.

\footnotetext{
*Corresponding author: avilova@yandex.ru
} 


\section{Methodological basis}

The main problems today are not only problems related to the elimination of emergency housing, the recognition of the status of houses that have an accident rate and, as a result, the provision of affordable and comfortable housing to the citizen [3].

One of the important problems can also be attributed to the imperfection of legislation in the field of emergency and dilapidated housing, and the misuse of the criteria of accident and dilapidation in the interests of certain persons. In addition, today there is a certain conflict zone between what the concept of accidents is put by residents and how it is reflected in the legislation. All these problems are large-scale and require certain measures and solutions[2,3].

There are three main groups of problems:

- the problem of lack of effective legal regulation;

- the problem of the lack of effective management mechanisms in this area;

- the problem of Economics and budgeting;

Regarding the problem of regulatory regulation of emergency and dilapidated housing, some shortcomings of existing laws have already been noted. It should be emphasized that the concept of "dilapidation" has disappeared from the legislation. As part of the problem of legal regulation, it is also worth noting the lack of legal control mechanisms over entities that recognize the status of houses as dilapidated and dilapidated. For example, it is necessary to set strict deadlines for the resettlement of residents, if there is a threat of accident or dilapidation of the house upon the request of citizens[7].

Table 1. Main criterion.

\begin{tabular}{|c|c|}
\hline The emergency house & The old house \\
\hline $\begin{array}{c}\text { A building that may collapse at any time due to } \\
\text { changes to the building's main structures. State } \\
\text { of the house }\end{array}$ & $\begin{array}{c}\text { A building that ceases to meet the specified } \\
\text { operating requirements as a result of wear and } \\
\text { tear due to natural factors and external } \\
\text { influences }\end{array}$ \\
\hline
\end{tabular}

The problem of the lack of effective mechanisms for managing the sphere of emergency and dilapidated houses can be divided into a number of diverse questions, in particular, today:

- there are no effective mechanisms for reconstruction of houses;

- new construction of houses does not keep up with the retirement of the housing stock due to its aging;

- there are no principles of complexity and coordination in solving problems of dilapidated and dilapidated houses.

For example, the principle of complexity implies a global approach to solving problems of emergency housing. On the other hand, for example, insufficient construction rates create not only an imbalance in the reproduction of housing funds, but also an imbalance of supply and demand in the housing market, which in turn affects the solvency of the population[1].

Thus, the solution of the housing problem, namely the solution of the problem of emergency housing, should be considered comprehensively, taking into account many factors[5].

\section{Result}

The solution of these problems is possible only with the help of programs for resettlement from emergency housing. In this situation, a deeper and more thorough development, 
design and creation of an effective management model for this area, which would include regulatory entities, starting from the level of government and ending with citizens, is necessary. In addition, it is necessary to carefully study and monitor issues related to funding, as well as the provision of benefits. But the most important aspect should be the creation of a clear legal regulation in the field of emergency and dilapidated housing[3].

As of today, 408 houses are in disrepair in the city of Omsk. There are 3125 apartments in emergency apartment buildings with a total area of more than 110.230 square meters, where more than 8 thousand people live. The table shows the dynamics of the emergency housing stock in Omsk from 2014-2018. (Fig.1)

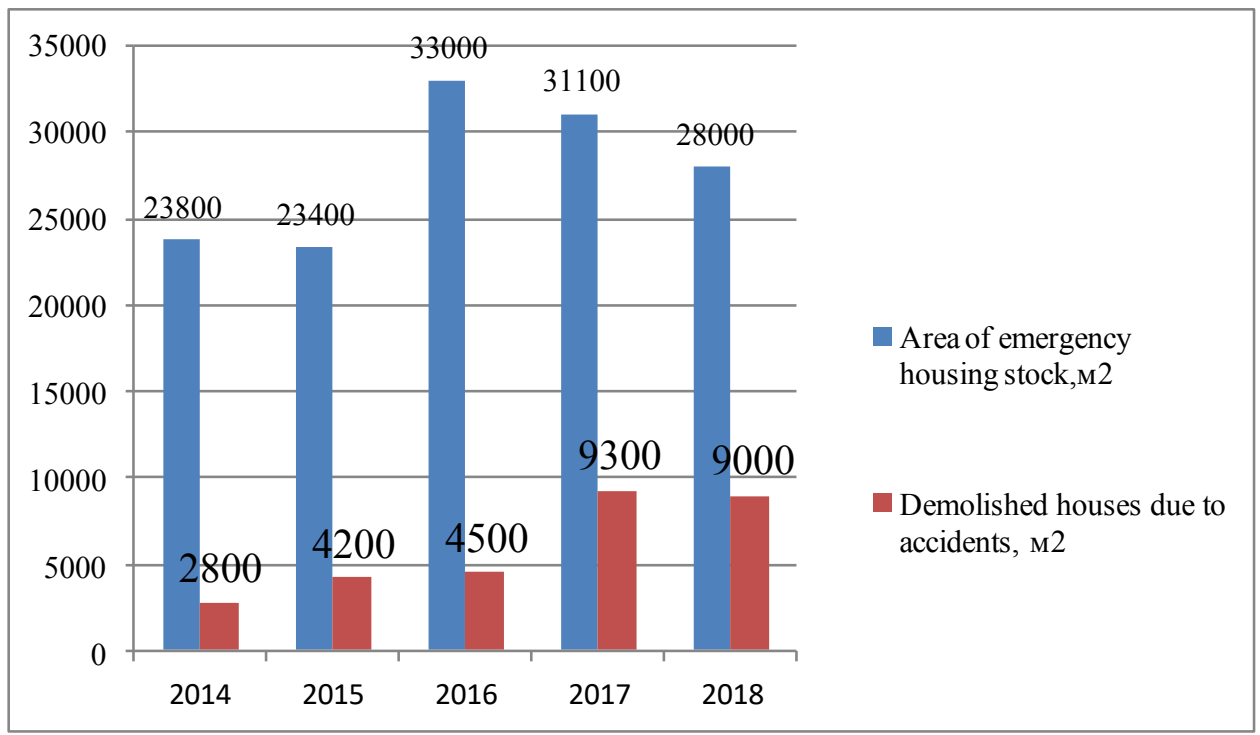

Fig. 1.. Area of emergency housing.

In 2017, the total area of the housing stock of the city of Omsk was 2243.9 thousand square meters. According to the results of monitoring the technical condition of apartment buildings as of 01.01.2018, the number of apartment buildings is 1.154 units (in 2016-1.171 units) with a total area of 1854.1 thousand square meters (in 2016 - 1770.8 thousand square meters). The share of the total area of the city's housing stock in 2017, which has a comprehensive improvement is $82.6 \%$.

As of 01.01.2018 area of old housing stock is 73.9 thousand square meters, which is 0.6 thousand square meters less than in 2016, the area emergency housing decreased by 2.3 thousand square meters and amounted to 28.8 thousand square meters of dilapidated housing in the city of Omsk has decreased due to the active implementation of measures on liquidation of emergency housing. In 2017, 30 emergency houses with a total area of 10 thousand square meters were demolished, which is almost 2 times higher than in 2016. Since the beginning of 2017, 15 multi-apartment residential buildings with a total area of 89.7 thousand square meters have been put into operation. and 11 thousand square meters of individual housing construction. In 2017, 100.7 thousand square meters of the total area of the housing stock were introduced[5].

The housing stock of the Omsk region according to Rosstat data for 2017 amounted to $34.400,000$ square meters the structure of the housing stock is represented by $89.7 \%$ private ownership, $8.8 \%$-municipal and $1.5 \%$-state and mixed ownership.

The total area of uninhabitable and emergency housing stock as of January 1, 2018 was 2599.5 thousand square meters. The old one is 1982.4 thousand square meters. Emergency - 
617.1 thousand square meters. The number of dilapidated and emergency residential buildings is 10243 , of which 1393 are emergency. The share of emergency and dilapidated housing stock in the entire housing stock as of January 1, 2017 was $7.7 \%$, including emergency-1.8\%. 110.3 thousand people lived in dilapidated and emergency housing stock, including 29.22 thousand people in emergency housing stock.

The regional address program of the Omsk region for the resettlement of citizens from emergency housing stock in 2019-2025, adopted on April 10, 2019.

The authorized Executive body of the Omsk region responsible for the implementation of the Program, the main Manager of budget funds - the Ministry of energy and housing and communal services of the Omsk region.

The goal of the Program is to reduce the share of emergency housing in the housing stock of municipalities in the Omsk region, creating conditions for ensuring a steady reduction in the unsuitable housing stock[6].

To achieve this goal, you need to solve the following tasks:

1. Providing citizens living in a housing stock that is deemed unfit for permanent residence by consolidating financial resources, including by attracting financial support from the Fund, with comfortable housing in residential buildings that meet the recommended housing requirements.

2. Demolition of 309 emergency apartment buildings.

The solution of these tasks is planned in cooperation with the Fund by financing measures for the relocation of citizens from the emergency housing stock in the same chronological sequence in which residential buildings are recognized as unfit for living and subject to demolition.

The total amount of funding is 3.322.396.264.55 rubles, including funds from the state Corporation of the Fund for assistance in reforming housing and communal services - 3225 894358.53 regional budget funds - 65.118.966. 40 rubles, local budget funds-31.382.939. 62 rubles.

Expected results of the Program implementation - the area of residential premises to be resettled with the Fund's financial support is 79.825 .5 sq. m.; the number of residents to be resettled with the Fund's financial support is 5.194.

The program is implemented on the territories of municipalities of the Omsk region, where there are apartment buildings recognized as emergency due to physical wear and tear during their operation and subject to demolition and reconstruction before January 1, 2017. The order of participation of municipalities in the program stages is determined based on the assessment of the availability of free municipal housing stock, formed land plots for the construction of apartment buildings. Local self-government bodies organize explanatory work and inform citizens who are subject to relocation from the emergency housing stock.

The main task after the demolition of an emergency house is to save the land and transform it.

The Ministry of construction of Russia proposed to impose restrictions on the use of land plots that are released after the demolition of emergency houses. This was announced by the Minister of construction and housing of Russia Vladimir Yakushev at a parliamentary hearing on the issue of relocation of citizens from emergency housing in the Federation Council. He noted that in a number of regions, land plots released under the Federal resettlement program were withdrawn from auctions for the implementation of commercial projects.

"As a result of discussions with the regions, any proposal to impose limits on the use of land that will be exempt due to Federal programs. They should be used as public spaces parks or Parking lots, which is not enough" - said the Minister.

If we talk about foreign experience, in order to facilitate the reconstruction of residential buildings in Germany, banks began to be created, with whose help and thanks to the 
relevant directives in the event of losses (in the case when the property security of the loan is impossible), enterprises began to carry out the reconstruction of apartments where tenants still lived. Profitable lending at $4-5 \%$ for a period of 10-12 years helped the successful reconstruction of housing in Germany. This approach was innovative for the housing sector[11].

In various parts of the UK, quite a large number of residents take the most proactive part in the reproduction of the housing stock. This approach allows you to choose the most profitable and effective ways in which it is possible to carry out reconstruction and, importantly, to implement it mainly without relocation[10]. In addition, the involvement of the population in restoration and restoration work through the Association of residents contributes to the creation of additional jobs, increasing the interest of residents and active interaction with the authorities. Often there are also situations when residents are United in a construction cooperative and carry out work on the reconstruction and improvement of their homes[7].

Funds that are used to pay residents for the implementation of modernization and improvement works usually come back at the same time as the rent for improving living conditions[6]. Determining the method of house reconstruction in the UK is related to the technical condition of the house. Work on the reconstruction of housing can be subsidized by the following ways:

- the local administration leaves a request to the Central government in order to get permission to issue a long-term loan;

- as for the payments made on the loan, as a rule, they are designed for a time period of about 60 years. Credit is provided by private banks. The local administration is responsible for paying off the loan. In most cases, as it usually happens, when paying for an apartment, the loan itself is returned back. Its requirements are quite profitable and amount to about 7 $8 \%$ per year.

- there is no acquisition of an overdraft from the Central government; this action is carried out with the help of state measures, which are characterized by an increase in taxes by local authorities;

- by selling new housing at a higher cost.

Analyzing the foreign experience of housing reconstruction, we can come to the following conclusions:

- the successful development of reconstruction in most European countries is ensured by the active participation of the state;

- the sources of financing for housing reconstruction were in different proportions funds of home owners, the state budget, investors, businesses, and so on;

- a notable feature of countries with strong market economies, which exists today in the field of housing reconstruction, as well as preventing its premature deterioration, is the presence of a progressive credit and financial mechanism[8].

Based on the above, we can conclude that at the moment it is necessary to adopt the positive experience of foreign countries, which is the most acceptable in the Russian realities of housing development .

Emergency housing is the most acute housing problem due to many factors:

1. Lack of conditions for safe living of people.

This issue cannot be resolved without the help of the state. Although all the problems are not new - they have moved from the level of state power to the municipalities. For the recognition of emergency houses and resettlement of residents, there are many obstacles :

2. There are not enough financial resources for the construction and purchase of housing;

3. Legal aspects are not brought to perfection;

4. The problem of buying out emergency housing from owners. 
The municipality can withdraw emergency premises for municipal needs. However, withdrawal occurs at market value. This leads to a problem with determining the market price.

\section{Conclusions}

In the course of this work, we came to the conclusion that the problems, that exist today in the field of emergency housing must be addressed in a comprehensive manner, using all available mechanisms and tools. It turns out that by adopting and implementing separate measures, we will not be able to resolve these problems in various aspects of this issue. Thus, only with the help of a unified and systematic approach, which will consist in improving the legal framework, increasing the volume and pace of housing construction for the average category of citizens, reducing the rate for mortgage lending, providing benefits, and creating a management system for this area, it will be possible to solve existing problems.

To solve the problem, it is necessary to have a clearly formulated housing policy in the field of emergency housing and mechanisms for its implementation. Using a unified and systematic approach, which will consist in improving the legal framework, increasing the volume and pace of housing construction, providing benefits, and creating a management system for this area, it will be possible to solve existing problems[6].

\section{References}

1. V. Ananiev, A. Potapov, Proc. for the building. Specialist. Universities, 3rd ed., Revised. And Corr. Higher. wk. (2005)

2. T. Avilova, A. Shirokova, I. Kustesheva, Moscow economic magazine №1, 8-9, (2019) doi:10.24411/2413-046X-2019-11013

3. T. Avilova, I. Kustesheva, A. Melnicova, Moscow economic magazine №1, 11 - 15 (2019) doi:10.24411/2413-046X-2019-11009

4. T.Avilova, I. Kustesheva, O.Buldakova, Journal №10, 12-13 (2019) doi:10.24411/2587-6740-2019-13044

5. A. Ermakova, Moscow economic magazine 49, №10 (2019) doi: 10.24411/2413046X-2019-10059

6. A. Sukharev, Ya. Krutskikh, Big legal dictionary (Gorodets, Moscow, 2002)

7. B. Reisberg, Modern economic dictionary (Publishing house, 2003)

8. Public cadastral map (2020) DOI: http://pkk.rosreestr.ru

9. Ch. Montgomery, Happy City: Transforming Our Lives through Urban Design (Farrar, Straus, and Giroux, NY, 2013)

10. J. Carter, S. Shorts, M. C. Wood, Strategic Environmental Assessment and Land Use Planning an International Evaluation (2005) doi: 10.4236/jtts.2018.83013

11. J. Gehl, Cities for people (Covelo, Washington, Island Press, London, 2010) 